\title{
СИНОНИМИЧНЫЕ ЛИНГВИСТИЧЕСКИЕ ТЕРМИНЫ В КИТАЙСКОЙ ЯЗЫКОВЕДЧЕСКОЙ ТРАДИЦИИ
}

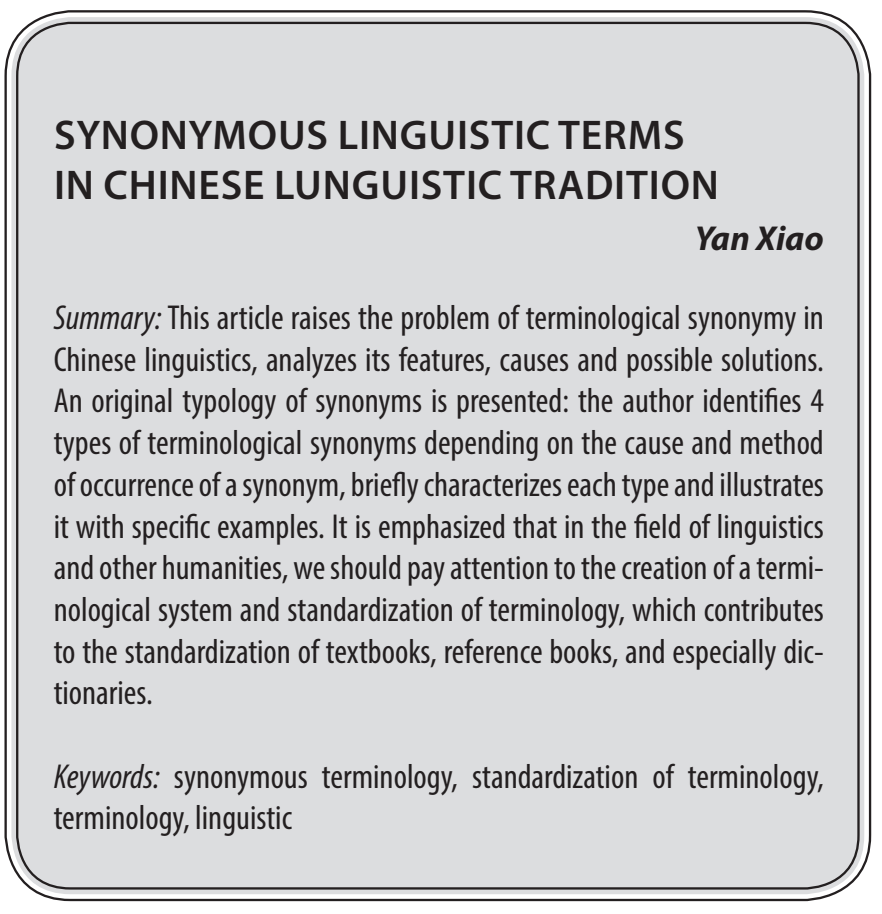

Некоторые обшие проблемы ^ингвистической терминологии

$\mathrm{O}$ бщеизвестно, что гуманитарные науки, в отличие от точных и естественных, испытывают недостаток в четко аргументированном терминологическом аппарате и строго упорядоченной терминологической подсистеме в рамках лексической системы языка: имеет место недостаточно точное и полное определение понятий, что закономерным образом создает проблему разграничения близких по смыслу понятий, их смешения и ошибочного использования; множественная интерпретация понятий, зафиксированная в словарных статьях и научных работах отдельных исследователей; терминологическая многозначность, с одной стороны, и синонимия (в том числе абсолютная синонимия, или терминологическая дублетность), с другой, вызванные неуместным заимствованием иноязычной лексики. В итоге мы сталкиваемся с проблемой недостаточной обоснованности существования того или иного термина, терминологической избыточности и вариативности в употреблении эквивалентной научной лексики. Особую роль в этом процессе играет перевод терминологических лексических единиц.

Данная проблема терминологической синонимии особенно актуальна для китайского языкознания, что связано, во-первых, с активным введением в оборот западной (англоязычной) терминологии в XX-XXI веках, а во-вторых,

\author{
Янь Сяо \\ Аспирант, Московский государственный университет \\ имени М.В. Ломоносова \\ yanxiao123@yandex.ru
}

Аннотация: В этой статье поднимается проблема терминологической синонимии в китайской лингвистике, анализируются ее особенности, причины и возможные способы решения. Представлена оригинальная типология терминов-синонимов: автор выделяет 4 типа терминологической синонимии в зависимости от причины и способа возникновения синонима, кратко характеризует каждый тип и иллюстрирует его конкретными примерами. Подчеркивается, что в области лингвистики и других гуманитарных наук мы должны уделять внимание созданию терминологической системы и стандартизации терминологии, чему способствует стандартизация учебников, справочников и в первую очередь словарей.

Ключевые слова: синонимичная терминология, стандартизация терминологии, терминология, лингвистика.

обусловлено самой китайской языковедческой традицией, и требует пристального внимания со стороны китайских лингвистов и лексикографов, на чем мы настаиваем в настоящей статье. В данной работе предлагается обзор современного состояния проблемы с целью ее дальнейшего разрешения.

\section{Синонимия в китайской мингвистической терминологии}

Что такое синоним? Традиционно синонимы определяются как «языковые знаки (слова, группы слов, обороты т.д.), которые служат для обозначения одного и того же явления действительности либо одного и того же понятия» [5]. Как часть лексической синонимии естественного языка явление терминологической синонимии занимает особое место и имеет ряд особенностей, что связано с функцией термина как инструмента научного познания. Отношение научного сообщества к терминологической синонимии неоднозначно.

Если мы имеем дело с терминами, чье предметное содержание полностью совпадает, принято говорить о терминологических дублетах: «терминологические дублеты - слова или словосочетания, которые объединяются особой терминологической соотнесенностью с одним и тем же научным понятием и объектом действительности» [4]. Дублетность нехарактерна для общелитературного языка, 
однако часто встречается в терминологии, особенно в китайской лингвистической терминологии.

Синонимы в китайской лингвистической терминосфере можно разделить на четыре типа в зависимости от причин их возникновения:

\section{(1) Тип 洋泾浜语 [янцзинбан юй] - 皮钦语 [nицинь юй]}

Оба данных термина служат для обозначения искусственно возникшего языка с упрощенной структурой, подразумевающего неизбежное искажение норм языка-источника и служащего для межэтнического общения (пиджин в русской терминологии).

Слово 洋泾浜语 [Янцзинбан] - это название китайского ручья и прилегающей к нему портовой зоны, которое отсылает к шанхайской французской концессии - особой территории Шанхая, находившейся под французским руководством в 1849-1946 гг.

Язык, используемый в портовой зоне, то есть в зоне Янцзинбан, представлял собой смешанный язык, в котором китайская грамматика была дополнена иноязычной лексикой (например, английской). Со временем такой смешанный язык получил название «янцзинбан юй», которое является оригинальным китайским названием.

Тем не менее некоторые китайские ученые не используют термин «янцзинбан юй», имеющий китайское происхождение, но предпочитают употреблять вместо него эквивалентный термин, «пицинь юй», который возник путем транслитерации ныне общеупотребимого англоязычного термина «pidgin», который, в свою очередь, представляет собой вариант неправильного китайского произношения английского слова «business».

Характерной чертой этого типа синонимии является то, что в рамках синонимичной пары один термин является исконно китайским, а другой возник путем заимствования из иностранного языка (существует два способа ввести иноязычные термины в китайскую терминосферу: транслитерация и транскрипция).

Еще одним примером синонимии данного типа является следующая пара терминов-синонимов: 混合语 (смешанный язык) - 克里奥尔语 (креольский язык).

\section{(2) Тип词序[цы сюй] - 语序 [юǔ сюŭ]}

Термины «цы сюй» и «юй сюй» обозначают порядок соединения синтаксических единиц (порядок слов в словосочетании, предложении и т.д.).

В термине 词序 [цы сюй] первый иероглиф词 [цы] означает «слово», следовательно, данный термин в первую очередь указывает именно на порядок слов и воспринимается носителями языка как связанный со словами. В термине 语序 [юй сюй] первый иероглиф 语 [юй] имеет более широкое значение («юй» - слово, предложение и язык), следовательно, термин в целом имеет более широкое значение и лучше описывает синтаксическую структуру языка. По этой причине некоторые китайские ученые считают термин «юй сюй» более подходящим. 语序 [юй сюй] был принят в Китае в качестве основного термина, что получило закрепление в учебниках, тем не менее термин 词序 [цы сюй] также продолжает использоваться.

Особенностью данного типа синонимии является механизм возникновения дублирующего термина, не связанный с переводческим процессом: на первом этапе утверждается и получает распространение первый термин, однако на втором этапе авторитетные представители научного сообщества выступают с критикой данного термина и предлагают более подходящий вариант.

(3) Тип分析语 [фэнь си юй] (аналитический язык) 孤立语 [гу ли юй] (изолирующий язык) - 词根语 [цы гэнь юй] (корневой язык)

Многие термины, которые вошли в состав китайской терминосферы, представляют собой заимствования из других языков, в первую очередь из английского, которые проникли в китайскую культуру при помощи перевода, а именно калькирования. Так, термин 分析语 [фэнь си юй] является калькой с английского analytic language, термин 孤立语 [гу ли юй] - с английского isolating language, 词根语 [цы гэнь юй] - с английского amorphous language. Принципиально важно, что структура из трех синонимичных терминов (analytic language - isolating language - amorphous language), которая существует в английском языке, была сохранена при переводе и перенесена в китайский язык под влиянием исходного языка в виде синонимов 分析语 [фэнь си юŭ] - 孤立语 [гу ли юŭ] - 词根语 [ Цы гэнь юй]. Характерной чертой этого типа синонимии является возникновение терминов-синонимов в китайском языке путем перевода иностранных терминов, при этом имеет место заимствование всей синонимической цепочки исходного языка, и внутри сформировавшейся группы терминологических дублетов все термины оказываются заимствованными, так как изначально отсутствовали эквиваленты в китайском языке. По такому же принципу в китайской лингвистической терминологии возникла пара синонимов 词组 (словосочетание) - 短语 (фраза).

\section{(4) Тип 声符 [шэн фу] - 声旁 [шэн naн] - 音旁 [инь naн]}

Для обозначения фонетической графемы в иероглифе в китайской терминологии существует три синонима: 声符 [шэн фу] - 声旁 [шэн пан] - 音旁 [инь пан].

Отличительной чертой таких синонимичных терминов 
является то, что они имеют китайское происхождение и отражают диахронический срез языка, его историческую природу или фиксируют определенную точку зрения говорящего.

Приведем пример. Китайский язык - явление сложное, многосоставное и неоднозначное. С одной стороны, термин «китайский язык» является многозначным. С другой стороны, в современном Китае существует несколько вариантов обозначения понятия «китайский язык» и различных его разновидностей. По временному признаку выделяется пара 官话 [гуаньхуа] - 普通话 [nутунхуа], члены которой указывают на разные исторические периоды. Так, при династиях Мин и Цин язык устного общения при дворе именовался官话 [гуаньхуа] (букв. язык чиновников). После основания КНР утвердилось название普通话 [nутунхуа] (мандаринский), которое сегодня служит для обозначения официального языка в Китайской Народной Республике.

Также синонимы данного типа могут выражать разные точки зрения на предмет: рассмотрим группу терминов 中 国话 [чжун го хуа] - 汉语 [хань уй] - 中文 [чжун вэнь]. Все три термина обозначают китайский язык, но в разных аспектах. Термин 中国话 [чжун го хуа] указывает на принадлежность к стране, 汉语 [хань уй] - на этническую принадлежность, а 中文 [чжун вэнь] относится к языку, который используется в общинах Юго-Восточной Азии и за рубежом.

\section{Норма и терминологическая синонимия: лексикографический аспект}

Проблема нормы в китайской лингвистической терминологии, страдающей от избытка синонимов, представляется нам чрезвычайно сложной и не имеющей одного единственно верного решения. От научного сообщества Китая требуется обратить на нее внимание, выработать единый подход к проблеме и в соответствии с ним сузить синонимическое поле лингвистических терминов, отграничить их друг от друга. Отметим, что установление терминологической нормы в гуманитарных науках, в том числе в языкознании, не обязательно должно соответствовать естественнонаучному подходу, согласно которому осу- ществляется унификация и выбирается единый стандарт. В силу своей специфики гуманитарные дисциплины признают вариативность и значимость каждой отдельной ситуации. Это относится и к такой проблеме лингвистики, как терминологическая синонимия, которая, как мы убедились, отличается неоднородностью и включает в себя несколько подтипов. Поэтому при стандартизации синонимичных китайских терминов и разграничении сферы их употребления необходимо учитывать своеобразие синонимических отношений в каждом конкретном случае.

Внутри китайской лингвистической терминосферы можно выделить, с одной стороны, термины китайского происхождения, а с другой стороны, термины, заимствованные из других языков. Проблема терминологической синонимии актуализируется во время переводческого процесса, когда разные переводчики обращаются к разным словарям, в которых названия научных терминов иностранного происхождения с одинаковым содержанием не совпадают. Появление избыточных синонимичных терминов в китайском лингвистическом дискурсе фактически вызвано ошибками в некоторых влиятельных словарях.

Наиболее эффективным средством улучшения ситуации, сложившейся в современной китайской лингвистической терминологии, может стать разработка рекомендаций со стороны авторитетных китайских лингвистов и лексикографов, а также стандартизация учебной, научной, справочной литературы, и в первую очередь словарей. Учебники и справочники по лингвистике, безусловно, являются важными инструментами профессионального общения. Двуязычные словари играют особую роль в стандартизации терминологии. Однако первым шагом должно стать признание самого факта существования проблемы и ее тщательное изучение, чтобы затем выработать механизм оптимального решения. Мы надеемся, что будет создан общепринятый механизм для улучшения учебников и справочников, которые играют ключевую роль в процессе стандартизации терминов и, следовательно, в решении проблемы терминологической синонимии.

\section{ЛИТЕРАТУРА}

1. Иванова Г.А. Терминологическая синонимия как коммуникативно-прагматический феномен // Вестник Нижегородского университета им. Н.И. ЛобачевСКого. 2015. № 2 (2). С. 406-410.

2. Толикина Е.Н. Некоторые лингвистические проблемы изучения термина // Лингвистические проблемы научно-технической терминологии. М., 1970. С. 53-67.

3. Лю Юнцюань, Словарь многоязыковой контрастной лингвистики // Издательство Пекинского языкового института, 1988.

4. Головин Б.Н., Кобрин Р.Ю. Лингвистические основы учения о терминах: учеб. пособие. М., 1987. С. 54.

5. Grimm H.-J. Untersuchungen zu Synonymie und Synonymitat durch Wortbildung im neueren Deutsch / H.-J. Grimm // Ein Beitrag zur Theorie der deutschen Synonymik, dargestellt an Beispielen aus dem Bereich des Substantivs: Diss.B . Leipzig, 1970. P. 165 